\title{
PREDICTORS OF WORK-RELATED WELL-BEING IN THE BRAZILIAN PSYCHOLOGY LITERATURE
}

\author{
HEILA M. S. VEIGA ${ }^{1}$ \\ (D) https://orcid.org/0000-0002-7429-8124 \\ PEDRO A. CORTEZ \\ (iD) https://orcid.org/0000-0003-0107-2033
}

To cite this paper: Veiga, H. M. S., \& Cortez, P. A. (2020). Predictors of work-related well-being in the Brazilian Psychology literature. Revista de Administração Mackenzie, 21(4), 1-27. doi:10.1590/ 1678-6971/eRAMG200094

Submission: May 15, 2019. Acceptance: Mar. 10, 2020.

Federal University of Uberlândia (UFU), Uberlândia, MG, Brazil.

2 Tuiuti University of Paraná (UTP), Curitiba, PR, Brazil. Methodist University of São Paulo, São Paulo, SP, Brazil.

\section{(c) $\mathbf{B Y}$}




\section{ABSTRACT}

Purpose: We aimed to identify the effects of predictors of work-related well-being in the Brazilian Psychology literature.

Originality/value: Researchers have focused on employee well-being to optimize working conditions and work performance in organizations. Despite a long research tradition about well-being, the predictors of employee well-being are not clear in the Brazilian literature.

Design/methodology/approach: First, in the literature review, we selected five studies using the descriptor "well-being" in the Brazilian portal of Electronic Journals in Psychology (Periódicos Eletrônicos em Psicologia [PePSIC]) and applied inclusion and exclusion criteria. Next, we compiled those studies' evidence to perform a meta-analysis using the software Jamovi 0.9.5.12 and the plugin MAJOR Meta-analysis 1.0.0 R.

Findings: The prediction of employee well-being - performed by means of intra-individual variables, connections with organizations and labor (O\&L), and macro variables - was clear about the positive and negative impacts of variables on well-being. However, further research studies are necessary, especially those in the interface with Administration and other areas, in order to optimize the generalization of the effects we found. In summary, this study contributes to the field of study by presenting preliminary evidence to elaborate high impact, evidence-based policies and practices on people management, including a possible interdisciplinary association between Psychology and Administration.

\section{KEYWORDS}

Well-being. Working conditions. Labor. Literature review. Meta-analysis. 


\section{INTRODUCTION}

The comprehension of personal characteristics and positive psychological states has been a growing agenda in the optimization of labor conditions and employees' performance at work (Görgens-Ekermans \& Steyn, 2016). Developing positive conditions in labor organizations can maximize individual and group occupational success (Allen \& McCarthy, 2015), because mindset shifts, concerning the ways of organizing work have increasingly prioritized the balance between decent working and good living conditions, as those variables highly affect the quality of the work performed (Di Fabio \& Kenny, 2016). In this context, investigations on Positive Psychology have highlighted models that can favor maximum human performance and, simultaneously, benefit employee well-being (Donaldson, Dollwet, \& Rao, 2015).

The study and understanding of well-being and the positive aspects of human experience has been among the main topics approached by Psychology in the 21st century (Adler \& Fleurbaey, 2016; Seligman \& Csikszentmihalyi, 2000; Snyder \& Lopez, 2002). The increasing comprehension of phenomena and the amount of research carried out are noticeable (Diener, Oishi, \& Tay, 2018). Among the concepts regarding the understanding of the positive aspects of work contexts, well-being is central. It has a long research tradition in Brazilian and international literatures and a high impact in work contexts. When analyzing this field of study by means of an integrative review of the international literature, Sonnentag (2015) found that wellbeing could refer both to hedonic experiences - in which one feels good and to eudaimonic experiences - which include one's fulfillment and purpose.

The hedonic perspective presents the subjective well-being, which refers to a subjective state of happiness and comprises three dimensions: life satisfaction, the experience of positive affect, and the absence of negative affect. The first one is in the cognitive dimension, while the others are in the affective dimension of well-being (Ryan \& Deci, 2001). The eudaimonic perspective presents the term psychological well-being to designate well-being associated with the realization of one's full potential, being a multidimensional construct (Ryff \& Keyes, 1995). On the one hand, subjective well-being is based on the evaluation of life satisfaction and on balance between positive and negative affections that reveal happiness. On the other hand, the theoretical conceptions of psychological well-being are based on psychological formulations on human development and human abilities to face life challenges (Siqueira \& Padovam, 2008). Thus, subjective well-being and psychological well-being are different but related constructs (Keyes, Shmotkin, \& Ryff, 
2002). In both conceptions, well-being varies according to personal (Houben, Noortgate, \& Kuppens, 2015) and environmental (Moen et al., 2016) factors, which may maximize or reduce the well-being daily experienced by individuals (Bliese, Edwards, \& Sonnentag, 2017).

Research on work-related well-being has advanced, and its empirical evidence points out that well-being is a predictor of productivity and desirable behavior at work (Danna \& Griffin, 1999; Deci \& Ryan, 2008; Diener \& Seligman, 2004). It also has a positive relation with commitment and customer satisfaction, and a negative relation with turnover of staff (Harter, Schmidt, \& Keyes, 2003; Robertson \& Cooper, 2011). Thus, organizations should invest in employee well-being as a management strategy (Pruyne, 2011). Different theoretical models have integrated the well-being construct with other individual and organization variables, such as the conservation of resources theory (Hobfoll, 1989), the job demands-resources model (JD-R) (Demerouti, Bakker, Nachreiner, \& Schaufeli, 2001), and the broaden-andbuild theory (Fredrickson, 1998).

Hobfoll's (1989) conservation of resources theory states that people with more resources are less vulnerable to resource losses and have more abilities to handle new resources. Resources are defined as aspects valued on their own by individuals (self-esteem, good health) or that help them obtain new resources (money, social support). JD-R is an occupation health model that explains how positive and negative organization indicators related to job demands and job resources are related to work motivation and burnout. This interaction between job resources and job demands affects the level of well-being (Bakker \& Demerouti, 2007). The broaden-and-build theory points out that positive emotions broaden an individual's ability to adapt to their environment, and this process has a long-term effect (Fredrickson, 2004).

Brazilian research studies have highlighted the importance of well-being in people's lives, including in the labor context, and they use different theoretical frameworks to understand this phenomenon (Siqueira \& Padovam, 2008; Cortez, Zerbini, \& Veiga, 2019). However, despite the central position of this topic, it is not clear how the predictors of well-being affect Brazilian organizational contexts. Those studies often recognize that the literature on the topic has improved definitions and operationalized measures for the phenomenon (Garcez, Antunes, \& Zarife, 2018; Santos \& Ceballos, 2013). However, there are gaps in the analysis of predictors of work-related wellbeing in the Brazilian literature using meta-analysis, which already exist in the international literature (Bowling, Eschleman, \& Wang, 2010; Lyubomirsky, King, \& Diener, 2005). 
Meta-analysis is a research method used to review the evidence found in the literature by combining and synthesizing the findings of two or more studies carried out independently, selected from a systematic literature review. It measures the statistic power between the relations tested (O'Sullivan, 2010). This method has been used in several areas of knowledge for decades, including Psychology. It is present in evidence-based Psychology and was officially recognized by the American Psychological Association (APA) (2005) more than a decade ago. However, its use in Brazilian research is incipient, with reviews on topics, such as work performance (Bendassolli, 2012), teaching work (Cortez, Souza, Amaral, \& Silva, 2017), retirement (Boehs, Medina, Bardagi, Luna, \& Silva, 2017), suicide at work (Cortez, Veiga, Gomide, \& Souza, 2019), and only one review on O\&L (Cortez, Zerbini, \& Veiga, 2019). The Brazilian literature lacks investigations using meta-analysis to assess work-related well-being, which justifies the need to explore this variable (Pantaleão \& Veiga, 2019). In short, understanding the effects of predictors of work-related well-being enables a critical assessment of the background of this variable and contributes to the formulation of optimized organization and management practices that can positively affect the working conditions experienced by Brazilian workers (Cortez, Zerbini, \& Veiga, 2019).

In the international literature, the previous mapping of predictors of well-being has played an important role in the formulation of management strategies and evidence-based health promotion practices, exerting positive impacts on workers and organizations (Guest, 2017; Görgens-Ekermans \& Steyn, 2016; Müller, Heiden, Herbig, Poppe, \& Angerer, 2016; Van Den Heuvel, Demerouti, \& Peeters, 2015; Van Wingerden, Bakker, \& Derks, 2017). In general, these international practices are based on the understanding that promoting employee well-being is associated with different levels of performance, whose different impacts should be analyzed in the work context and, more comprehensively, in daily activities (Breslow et al., 2016; Douglas, Lennon, \& Scott, 2017). Thus, aiming to contribute to an evidence-based research and practice agenda to promote employee well-being in Brazil, this study conducts meta-analysis research to identify the effects of predictors of work-related well-being found in the Brazilian Psychology literature.

\section{METHOD}

By means of an exploratory search in the Terminology in the Psychology database of the Health Virtual Library in Psychology (BVS-Psi Brazil), we 
selected the descriptor to find the research studies. In the database, we did not find any term specifically related to well-being and work, so we decided to use "well-being" in a generic way. We also did not determine a period of time in order to cover the greatest amount of evidence available in the literature.

For this review, we chose the portal of PePSIC database, due to its emphasis on Psychology and related fields of knowledge in the Brazilian literature. Previous evidence supports the selection of this database. It is necessary to systematize previous data on well-being according to specific fields and contexts, given the high theoretical and empirical diversity proposed on this theme (Garcez et al., 2018). Meta-analytical studies with high scopes of analysis often have high heterogeneity, making it difficult to compile evidence in a parsimonious model. Thus, comparing the effects of previous variables without first organizing evidence and empirical models for each field and contexts separately may bias the search and make the evidence proposed through meta-analysis incomprehensible. This concern also justified the restrictive criterion to choose the database and the nationality of studies, i.e., Brazilian research studies (Stroup et al., 2000).

The search for the descriptor "well-being" in the PePSIC resulted in 34 complete articles. The inclusion criteria were: 1 . research studies on employee well-being as an output variable; and 2. empirical relationships between previous variables and employee well-being. The exclusion criteria were the following: qualitative or monographic research studies without empirical relationships on work-related well-being. After reading the titles and abstracts, we excluded 25 studies for not addressing work-related wellbeing. As a result, we read nine complete articles. We excluded four of them because they are qualitative studies without quantitative evidence about the predictors of work-related well-being. Finally, we identified five studies and compiled their evidence to perform meta-analysis. Following the Preferred Reporting Items for Systematic Reviews and Meta-Analyses (Prisma) Statement, we elaborated a diagram to describe the procedure used to identify and select the articles (Urrútia \& Bonfill, 2010). Figure 2.1 synthesizes the procedures adopted.

In order to compile the studies' evidence into data to run the metaanalysis, we designed descriptive tables with the following information: 1. authorship; 2. variables measured; 3 . sample size; 4 . effect size of the variable on employee well-being; 5 . effect polarity ( 1 = positive; $-1=$ negative). When correlation indexes were not reported, we converted regression estimates into correlation coefficients (Peterson \& Brown, 2005). The statistical 
software used to generate descriptive statistics, and the meta-analysis model was Jamovi 0.9.5.12 (Jamovi, 2018).

\section{(Figure 2.1)}

\section{FLOW DIAGRAM OF REVIEW AND META-ANALYSIS PROCEDURES}
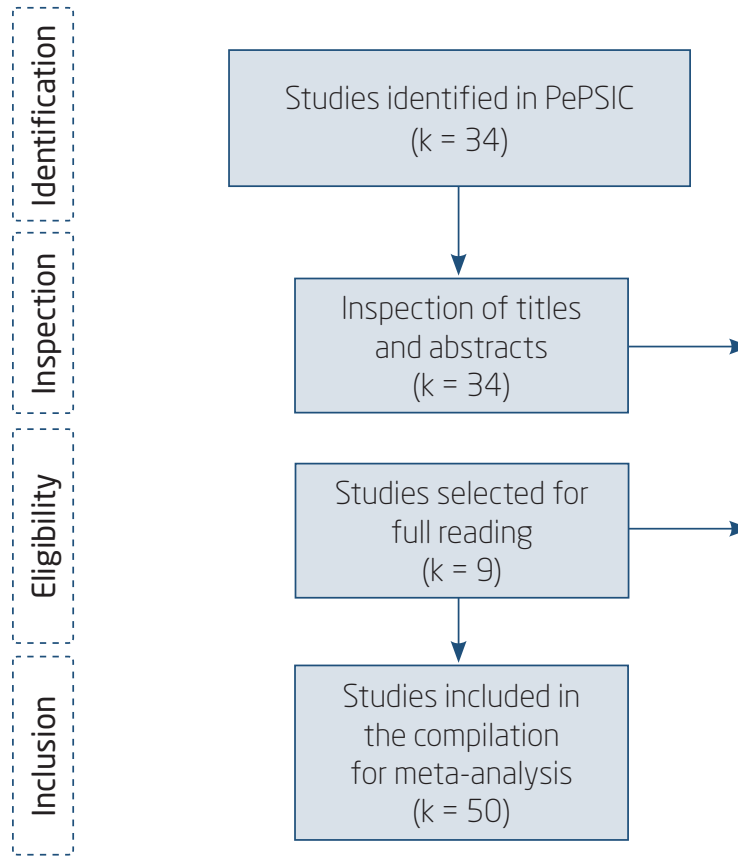

Studies excluded for not approaching work-related well-being $(k=25)$

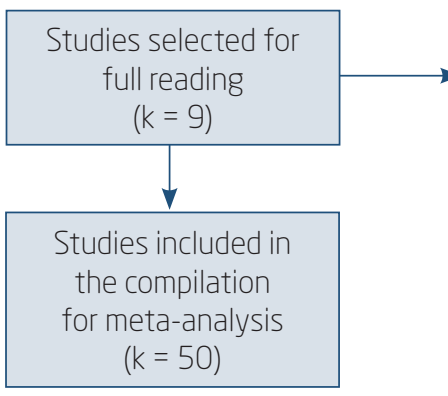

Studies excluded for being qualitative studies $(k=4)$

Source: Adapted from Moher, Liberati, Tetzlaff, Altman, and Prisma Group (2009).

The plugin MAJOR Meta-analysis 1.0.0 R (Hamilton, 2018) was used specifically to generate the meta-analysis model. Meta-analysis statistics were carried out through Fisher r-to-z-transformation (Silver \& Dunlap, 1987). The model covered mixed effects due to the high heterogeneity of the studies and, in most of the cases, to their sampling, which was restricted to organizational contexts (Brockwell \& Gordon, 2001). The adjustment indexes evaluated were Akaike information criterion (AIC) and Bayesian information criterion (BIC) (Burnham \& Andersonand, 2004). The residual plot asymmetry was also analyzed (Sterne et al., 2011). Additionally, FailSafe $\mathrm{N}$ was also covered by the Rosenthal criterion, in order to verify the sample size needed to impact the effects identified (Orwin, 1983). 


\section{RESULTS}

The study sample pointed out several predictors related to employee well-being. Generally, predictors comprised intra-individual variables, connections with O\&L, and macro variables that affected employee well-being. Multiple measures were used to assess employee well-being, encompassing both the eudaimonic and hedonic perspectives. Figure 3.1 shows the list of authors, predictors and measures used to assess well-being and summarize the statistics used in the meta-analysis models.

\section{(Figure 3.1)}

\section{DESCRIPTIVE SYNTHESIS OF EMPIRICAL EVIDENCE AND COMPILATION OF DATA FOR META-ANALYSIS}

\begin{tabular}{|c|c|c|c|c|c|}
\hline Authors & Predictors & Well-being scales & $\mathrm{n}$ & $r$ & Co \\
\hline \multicolumn{6}{|l|}{ Intra-individual variables } \\
\hline $\begin{array}{l}\text { Souza, Aguiar, and Carneiro } \\
\text { (2018) }\end{array}$ & Negative affect & EBS (Albuquerque \& Tróccoli, 2004) & 310 & -0.33 & -1 \\
\hline $\begin{array}{l}\text { Hirschle, Gondim, Alberton, } \\
\text { and Ferreira (2019) }\end{array}$ & Stress & EBET (Paschoal \& Tamayo, 2008) & 480 & -0.57 & -1 \\
\hline Carneiro and Fernandes (2015) & $\begin{array}{l}\text { Internal locus of control at } \\
\text { work }\end{array}$ & EBPO (Dessen \& Paz, 2010) & 200 & 0.58 & 1 \\
\hline $\begin{array}{l}\text { Santos, Torres, and Zanini } \\
\text { (2011) }\end{array}$ & Internal locus of control & EBFP (Ferreira \& Torres, 2001) & 146 & -0.11 & -1 \\
\hline Santos et al. (2011) & External locus of control & EBFP (Ferreira \& Torres, 2001) & 146 & 0.40 & 1 \\
\hline Hirschle et al. (2019) & $\begin{array}{l}\text { Adaptive emotional } \\
\text { regulation }\end{array}$ & EBET (Paschoal \& Tamayo, 2008) & 480 & 0.28 & 1 \\
\hline Hirschle et al. (2019) & $\begin{array}{l}\text { Functional emotional } \\
\text { regulation }\end{array}$ & EBET (Paschoal \& Tamayo, 2008) & 480 & 0.25 & 1 \\
\hline Hirschle et al. (2019) & $\begin{array}{l}\text { Maladaptive emotion } \\
\text { regulation }\end{array}$ & EBET (Paschoal \&Tamayo, 2008) & 480 & -0.16 & -1 \\
\hline Hirschle et al. (2019) & $\begin{array}{l}\text { Dysfunctional emotion } \\
\text { regulation }\end{array}$ & EBET (Paschoal \& Tamayo, 2008) & 480 & -0.29 & -1 \\
\hline \multicolumn{6}{|l|}{ Connections with O\&L } \\
\hline Souza et al. (2018) & Organizational commitment & EBS (Albuquerque \& Tróccoli, 2004) & 310 & 0.34 & 1 \\
\hline Souza et al. (2018) & Satisfaction & EBS (Albuquerque \& Tróccoli, 2004) & 310 & 0.48 & 1 \\
\hline Alves, Neiva, and Paz (2014) & Management styles & EBP (Paz, 2004) & 321 & 0.18 & 1 \\
\hline Alves et al. (2014) & Material support & EBP (Paz, 2004) & 321 & 0.23 & 1 \\
\hline
\end{tabular}




\section{(Figure 3.1 (conclusion))}

DESCRIPTIVE SYNTHESIS OF EMPIRICAL EVIDENCE AND COMPILATION OF DATA FOR META-ANALYSIS

\begin{tabular}{|c|c|c|c|c|c|}
\hline Authors & Predictors & Well-being scales & $\mathrm{n}$ & $r$ & Co \\
\hline \multicolumn{6}{|c|}{ Connections with O\&L } \\
\hline Alves et al. (2014) & Salary & EBP (Paz, 2004) & 321 & 0.07 & 1 \\
\hline Alves et al. (2014) & Professional growth & EBP (Paz, 2004) & 321 & 0.17 & 1 \\
\hline Alves et al. (2014) & Social support & EBP (Paz, 2004) & 321 & 0.14 & 1 \\
\hline Souza et al. (2018) & $\begin{array}{l}\text { Organizational } \\
\text { entrenchment }\end{array}$ & EBS (Albuquerque \& Tróccoli, 2004) & 310 & -0.12 & -1 \\
\hline Alves et al. (2014) & Work overload & EBP (Paz, 2004) & 321 & -0.10 & -1 \\
\hline \multicolumn{6}{|l|}{ Macro variables } \\
\hline Alves et al. (2014) & Instrumental power & EBP (Paz, 2004) & 321 & -0.10 & -1 \\
\hline Alves et al. (2014) & Autocratic power & EBP (Paz, 2004) & 321 & -0.03 & -1 \\
\hline Alves et al. (2014) & Missionary power & EBP (Paz, 2004) & 321 & 0.33 & 1 \\
\hline Alves et al. (2014) & Meritocratic power & EBP $(\operatorname{Paz}, 2004)$ & 321 & 0.05 & 1 \\
\hline Alves et al. (2014) & Autonomous power & EBP (Paz, 2004) & 321 & 0.06 & 1 \\
\hline Alves et al. (2014) & Political arena & EBP (Paz, 2004) & 321 & -0.07 & -1 \\
\hline Santos et al. (2011) & Belief in a just world & EBFP (Ferreira \& Torres, 2001) & 146 & 0.17 & 1 \\
\hline
\end{tabular}

Note: $\mathrm{n}$ = sample size; $\mathrm{r}$ = effect magnitude; $\mathrm{Co}$ = control of polarity effect; EBS = Subjective Well-being Scale EBET = Work-related Well-being Scale EBPO = Individual Well-being in Organizations Scale; EBP = Individual Well-being Scale; EBFP = Physical and Psychological Well-being Scale.

Source: Elaborated by the authors.

Concerning their design, the research studies in the sample investigated the predictors of employee well-being in samples from organizations. The effects showed positive and negative polarities between the different levels of analysis and their respective predictors. For this reason, we listed the polarity of each predictor in the statistics summary to include it as a control variable, reduce the heterogeneity of the evidence reported in the meta-analysis, and allow the comparison of variables with different polarities.

\subsection{Intra-individual variables as predictors of employee well-being}

The general effect of intra-individual variables on the prediction of employee well-being was positive $(\beta=0.042 ; \mathrm{p}>0.05)$. The polarity of the 
effect used as a control in the model was positive $(\beta=0.35 ; \mathrm{p}<0.01)$. The variation between studies was reasonable $\left(\mathrm{T}^{2}=2.1 \%\right)$, with substantial heterogeneity $\left(\mathrm{I}^{2}=92.5 \%\right)$. The Fail-Safe $\mathrm{N}$ test demonstrated the need for a substantial sample to change the effect identified $(n=2000 ; p<0.01)$. The AIC and BIC indexes were, respectively, 3.352 and 3.190, as shown in Figure 3.1.1.

(Figure 3.1.1)

GENERAL EFFECT OF INTRA-INDIVIDUAL VARIABLES AND ADJUSTMENT INDEXES $(K=9)$

\begin{tabular}{|c|c|c|c|c|c|c|c|c|c|c|c|c|}
\hline \multicolumn{6}{|c|}{ Impact } & \multicolumn{7}{|c|}{ Adjustment } \\
\hline & Effect & Error & z & $P$ & [CI 95\%] & $T^{2}$ & $1^{2}$ & Gl & $Q$ & $p$ & AIC & $\mathrm{BIC}$ \\
\hline $\begin{array}{l}\text { Intra-individual } \\
\text { variables }\end{array}$ & 0.042 & 0.067 & 0.634 & $>0.05$ & {$[-0.089-0.175]$} & 0.021 & $92.50 \%$ & 8.00 & 94.757 & $<0.01$ & 3.352 & 3.190 \\
\hline Control & 0.351 & 0.067 & 5.336 & $<0.01$ & {$[0.227-0.491]$} & & & & & & & \\
\hline
\end{tabular}

Note: $\mathrm{k}$ = number of effects analyzed; control = effect polarity.

Source: Elaborated by the authors.

Among the predictors with negative polarity, stress had the greatest effect on reducing well-being $(\beta=-0.65)$. The internal locus of control at work had the greatest effect among predictors with positive polarity $(\beta=0.66)$. However, this evidence was partially conflicting with another effect of internal locus of control as a general dispositional characteristic, which had a negative impact on well-being $(\beta=-0.11)$. Figure 3.1.2 shows the effect played by each intra-individual variable in the prediction of workrelated well-being.

Despite this conflicting aspect between the internal locus of control in general and at work, the effects analyzed in intra-individual predictors had no asymmetry (Kendall Tau $=0.233 ; \mathrm{p}=0.417$ ). In general, our analysis clearly showed the positive and negative impacts of intra-individual variables on employee well-being. 


\section{(Figure 3.1.2)}

\section{EFFECT, CONFIDENCE INTERVAL, AND ASYMMETRY OF EACH INTRA-INDIVIDUAL VARIABLE}

Negative affect

Stress

Internal locus of control

Maladaptive emotion regulation

Dysfunctional emotion regulation Internal locus of control at work

External locus of control

Adaptive emotional regulation

Functional emotional regulation

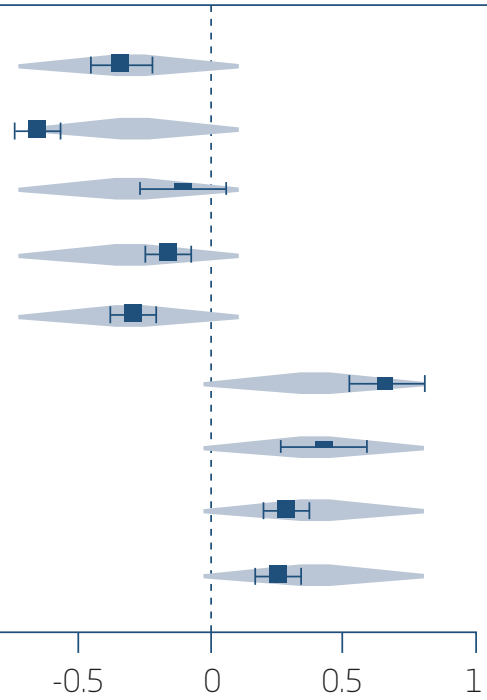

$-0.34(-0.45,-0.23)$

$-0.65(-0.74,-0.56)$

$-0.11(-0.27,-0.05)$

$-0.16(-0.25,-0.07)$

$-0.30(-0.39,0.21)$

$0.66(0.52,0.80)$

$0.42(0.26,0.59)$

$0.29(0.20,0.38)$

$0.26(0.17,0.35)$

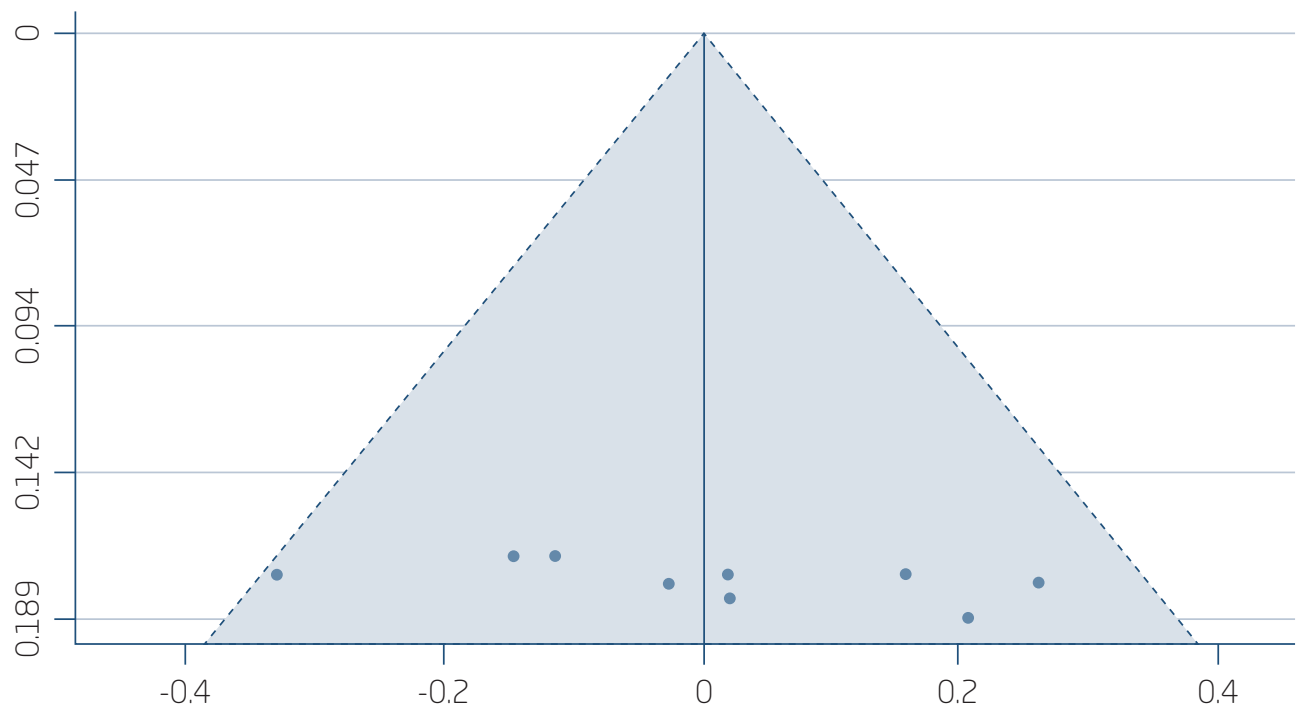

Source: Elaborated by the authors. 


\subsection{Connections with 0\&L as predictors of employee well-being}

Connections with O\&L had a positive effect on the prediction of employee well-being $(\beta=0.064 ; p>0.05)$. The effect of the control polarity was also positive $(\beta=0.174 ; \mathrm{p}>0.01)$. The variation statistics between the studies was moderate $\left(\mathrm{T}^{2}=1.60 \%\right)$, as well as the heterogeneity $\left(\mathrm{I}^{2}=84.04 \%\right)$. The sample necessary to change the effect analyzed using Fail-Safe $\mathrm{N}$ was small $(\mathrm{n}=236 ; \mathrm{p}<0.01)$. The AIC and BIC indexes were, respectively, -1.531 and -1.693 , as shown in Figure 3.2.1.

\section{(Figure 3.2.1)}

\section{GENERAL EFFECT OF CONNECTIONS WITH O\&L AND ADJUSTMENT INDEXES ( $K=9$ )}

\begin{tabular}{|c|c|c|c|c|c|c|c|c|c|c|c|c|}
\hline \multicolumn{6}{|c|}{ Impact } & \multicolumn{7}{|c|}{ Adjustment } \\
\hline & Effect & Error & z & $p$ & [CI 95\%] & $T^{2}$ & $1^{2}$ & $\mathrm{Gl}$ & Q & $\mathrm{p}$ & AIC & BIC \\
\hline Connections & 0.064 & 0.056 & 1.140 & $>0.05$ & {$[-0.047-0.175]$} & & & & & & & \\
\hline Control & 0.174 & 0.056 & 3.090 & $<0.01$ & [0.064 - 0.286] & & & 0.00 & 4.7 .40 & 0.01 & 1. & ב כ. \\
\hline
\end{tabular}

Note: $k$ = number of effects analyzed; control = effect polarity.

\section{Source: Elaborated by the authors}

In the analysis of the variables of connections with O\&L, organizational entrenchment showed the greatest effect with negative polarity $(\beta=-0.12)$, which was very close to the negative effect exerted by work overload, reducing employee well-being $(\beta=-0.10)$. Among the variables with positive polarity, satisfaction had the greatest predictive effect $(\beta=0.52)$. Material support was also an important positive predictor $(\beta=0.23)$, as shown in Figure 3.2.2.

Figure 3.2.2 shows a clear distribution of predictors with positive and negative polarity. However, the variable satisfaction presented an asymmetric occurrence, which surpassed the residual borderline value in the lower right portion of the graph. When analyzing the overall plot, asymmetry did not substantially impact the effects verified, which obtained a satisfactory Kendall Tau index $(0.236(p=0.439))$ for the model, considering the other variables. 


\section{(Figure 3.2.2)}

EFFECT, CONFIDENCE INTERVAL, AND ASYMMETRY OF CONNECTIONS WITH O\&L

Organizational entrenchment

Work overload

Organizational commitment

Satisfaction

Management styles

Material support

Salary

Professional growth

Social support
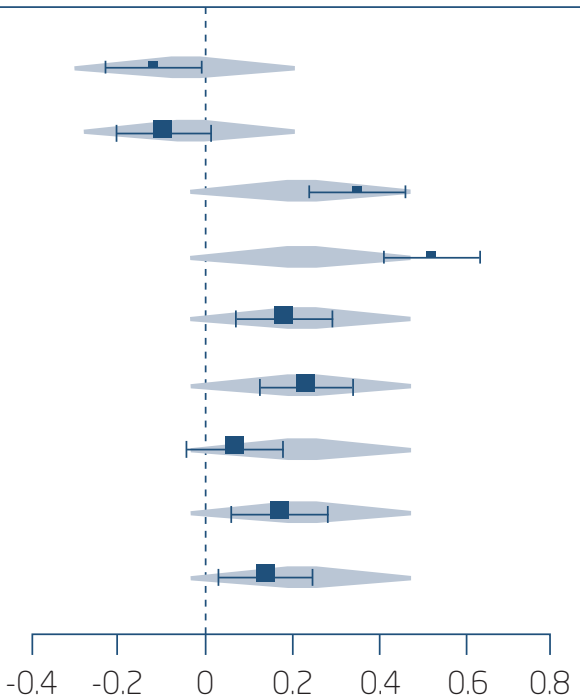

$-0.12(-0.23,-0.01)$

$-0.10(-0.21,-0.01)$

$0.35(0.24,0.47)$

$0.52(0.41,0.63)$

$0.18(0.07,0.29)$

$0.23(0.12,0.34)$

$0.07(-0.04,0.18)$

$0.17(0.06,0.28)$

$0.14(0.03,0.25)$

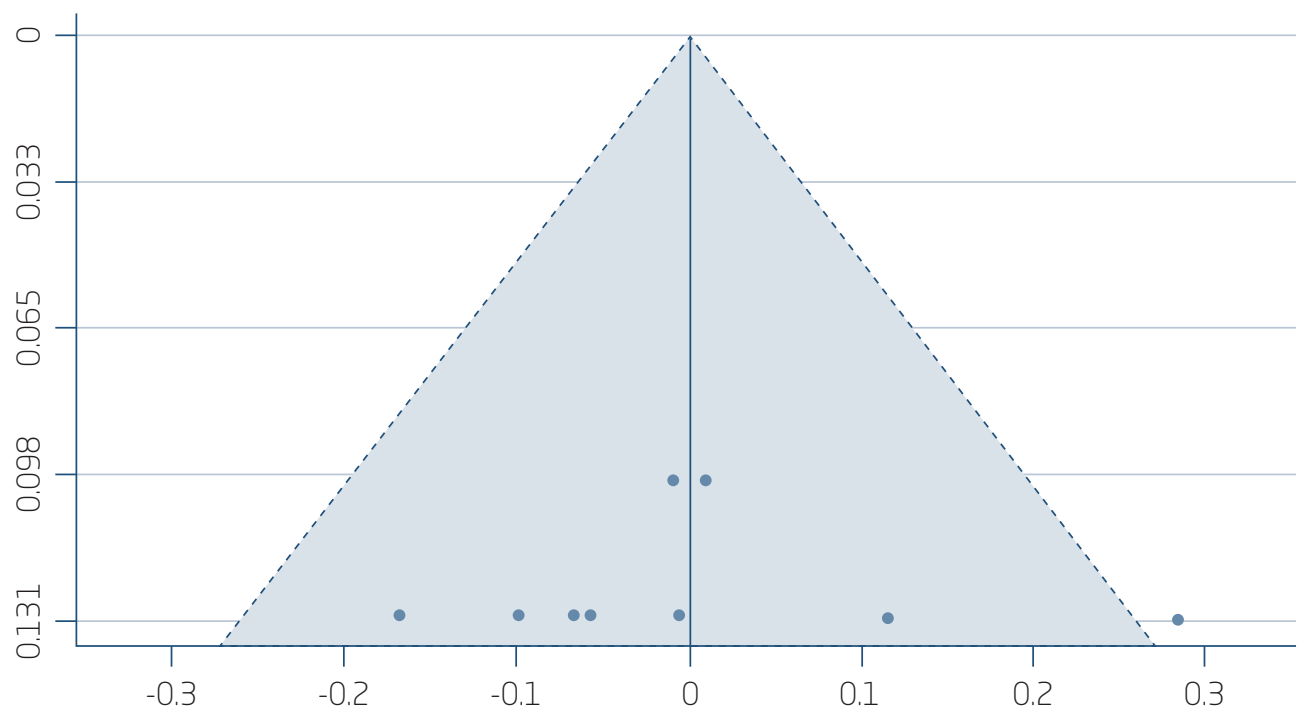

Source: Elaborated by the authors.

\subsection{Macro variables as predictors of employee well-being}

Macro variables positively predicted employee well-being $(\beta=0.044 ; \mathrm{p}>$ $0.05)$. The effect of control polarity was also positive $(\beta=0.044 ; \mathrm{p}<0.01)$. 
The variation between studies was reasonable $\left(\mathrm{T}^{2}=0.80 \%\right)$, with medium heterogeneity $\left(\mathrm{I}^{2}=71.93 \%\right)$. The Fail-Safe $\mathrm{N}$ had a robust sample size $(\mathrm{n}=$ 9000; $\mathrm{p}<0.01$ ). The AIC and BIC indexes were, respectively, -1.876 and -3.047. Figure 3.3.1 shows the effects and other adjustment indexes.

(Figure 3.3.1)

GENERAL EFFECT OF MACRO VARIABLES AND ADJUSTMENT INDEXES $(K=7)$

\begin{tabular}{|c|c|c|c|c|c|c|c|c|c|c|c|c|}
\hline \multicolumn{6}{|c|}{ Impact } & \multicolumn{7}{|c|}{ Adjustment } \\
\hline & Effect & Error & Z & P & [Cl 95\%] & $T^{2}$ & $I^{2}$ & Gl & Q & P & AIC & $\mathrm{BIC}$ \\
\hline Macro & 0.044 & 0.042 & 1.040 & $>0.05$ & {$[-0.039-0.127]$} & \multirow{2}{*}{0.008} & \multirow{2}{*}{$71.93 \%$} & \multirow{2}{*}{6.00} & \multirow{2}{*}{18.417} & \multirow{2}{*}{$<0.01$} & \multirow{2}{*}{-1.876} & \multirow{2}{*}{-3.047} \\
\hline Control & 0.111 & 0.042 & 2.610 & $<0.01$ & {$[0.028-0.194]$} & & & & & & & \\
\hline
\end{tabular}

Note: $k$ = number of effects analyzed; control = effect polarity.

Source: Elaborated by the authors.

Among macro variables, the instrumental power had the greatest effect with negative polarity $(\beta=-0.10)$, and the variables missionary power $(\beta=0.34)$ and belief in a just world $(\beta=0.17)$ had the greatest effect with positive polarity. In the residual analysis, all variables remained within the expected range, which contributed to the Kendall Tau index $=0.356$ $(\mathrm{p}=0.317)$, as seen in Figure 3.3.2.

\section{(Figure 3.3.2)}

\section{EFFECT, CONFIDENCE INTERVAL AND ASYMMETRY OF MACRO VARIABLES}

Instrumental power

Autocratic power

Political arena

Missionary power

Meritocratic power

Autonomous power

Belief in a just world

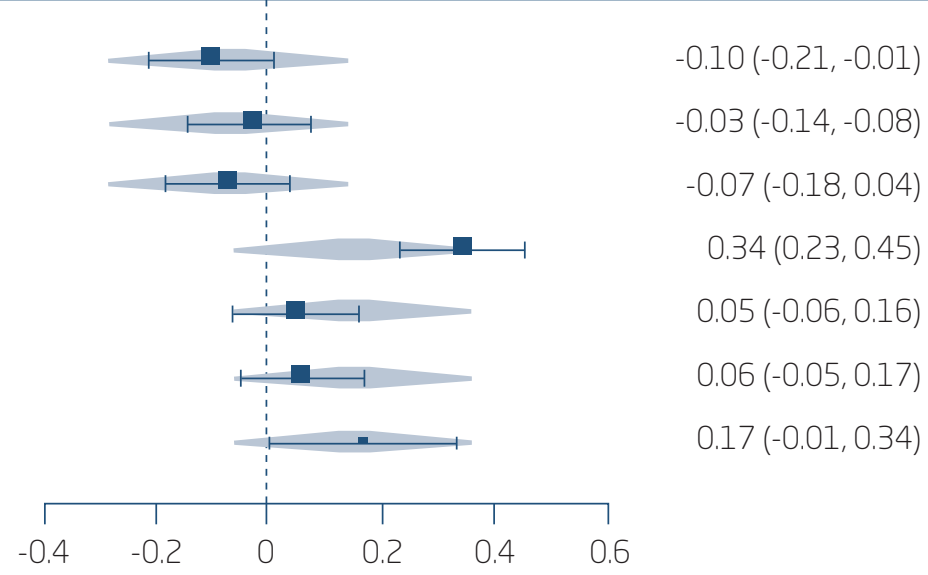

(continue) 


\section{(Figure 3.3.2)}

\section{EFFECT, CONFIDENCE INTERVAL AND ASYMMETRY OF MACRO VARIABLES}

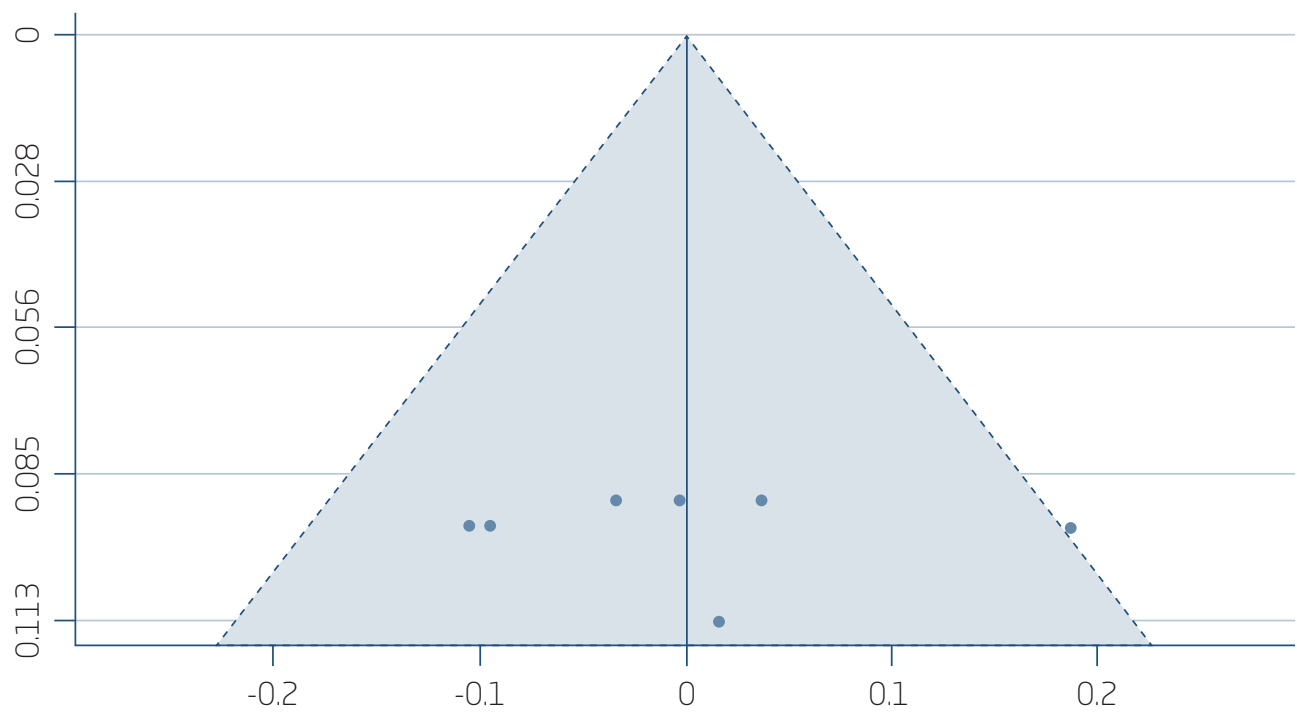

Source: Elaborated by the authors.

\section{DISCUSSION}

This study identified the effects of predictors of employee well-being. Based on meta-analysis models, we found a clear distinction between positive and negative predictor effects on work-related well-being. However, assessing the magnitude of the effects on each variable requires broader studies with compatible scales and variables, in order to maximize the level of statistical significance and, consequently, optimize the conditions of evidence generalization.

At the intra-individual level, stress, negative affect and maladaptive and dysfunctional emotional regulation are harmful to employee well-being. Thus, fostering actions to prevent health problems at work, emphasizing stress management and emotional self-regulation, is recommended (Bliese et al., 2017; Souza, Aguiar, \& Carneiro, 2018; Santos, Torres, \& Zanini, 2011). Self-regulation is a key variable in understanding the intra-individual predictors of employee well-being, given that adaptive and functional emotional regulation has a predominantly positive effect on employee wellbeing (Hirschle, Gondim, Alberton, \& Ferreira, 2019). Furthermore, from 
an empirical perspective, further studies can compare the effect caused by locus of control at work and locus of control as a general dispositional characteristic. In the meta-analytic model generated in the present study, it is not clear whether defining internal causality as a personal characteristic benefits or harms employee well-being (Carneiro \& Fernandes, 2015; Santos et al., 2011).

When analyzing the connections with O\&L, the negative effects of organizational entrenchment and work overload demonstrate the centrality of work design to optimize working conditions and improve employee wellbeing (Alves, Neiva, \& Paz, 2014; Souza et al., 2018). Specifically, work design (job assignments and ergonomics) should be improved to minimize work overload, organizational practices (policies for promotion, salary, and replacement of workers in the labor market), and organizational entrenchment (Van Wingerden et al., 2017). We reiterate the importance of work design when analyzing those connections with O\&L, whose effect had a positive polarity since positive predictors - such as material support, social support, salary, conditions for professional growth, and management style increased employee well-being (Van Den Heuvel et al., 2015). Thus, work design and management conditions should promote practices focused on material and symbolic support to employees, as, ultimately, these actions optimize connections with O\&L and positively affect employee well-being (Moen et al., 2016).

Satisfaction stands out among the variables of connection with O\&L (Souza et al., 2018), as it was the only one in the meta-analytical models that showed asymmetry in the effects modeled. Thus, we highlight the importance of further investigations on this variable, as asymmetry indicates a high level of bias (Sterne et al., 2011). We have the hypothesis that the labor context we chose for the meta-analysis, whose focus is work-related well-being, may have not allowed an appropriate comparison of effects, considering that satisfaction also covers one's personal aspects. In another meta-analytic investigation, Bowling et al. (2010) found a bidirectional relationship between job satisfaction and subjective well-being. The effect size indicated that the impact of well-being on satisfaction was stronger than the impact of satisfaction on well-being. Thus, future studies can focus on satisfaction evaluation models with the following predominant analysis factors: relationships with managers, relationships with colleagues, nature of work, among other aspects that have a stronger relationship with the work context. This emphasis encompasses more appropriately the relationship of satisfaction with employee well-being (Ferraz \& Lopes, 2015; Siqueira, 2008). 
At the macro level, instrumental power, autocratic power, and the political arena proved to be negative predictors and harmful to employee wellbeing, so they should be avoided (Alves et al., 2014). In general, these power configurations in organizations maintain a pattern of domination or imposition that favors some restrictive group; therefore, they are inadvisable to promote employee well-being (Katic \& Ingram, 2018). On the other hand, power configurations, such as autonomous, meritocratic and missionary powers, improve well-being, indicating that more autonomy and power given to specialists, as well as exercise of power towards a purpose, can increase employee well-being (Arcidiacono \& Di Martino, 2016). The variable belief in a just world is also worth mentioning, as it maximized employee well-being (Santos et al., 2011). As a social ideal within and outside work organizations, the exercise of restrained power is essential to improve employee well-being, as it is associated with greater positive purposes focused on justice (Prilleltensky, 2008).

The effect exerted by the belief in a just world is particularly interesting because it demonstrates that the promotion of employee well-being at different levels of analysis occurs in a transversal way, including the intraindividual level, connections with O\&L, and the macro-level inside and outside the organization. Power configurations inside organizations affect employee well-being, but so do beliefs about the world - employees' overall reality trabalhadores (Guest, 2017). For this reason, actions on workers' health should cover well-being in its entirety, which requires analyzing individuals inside and outside organizations and expanding the actions and practices to improve employees' biopsychosocial health beyond the work context (Cardoso \& Araújo, 2016). This means approaching spaces inside and outside organizations and, whenever possible, articulating them with public and private policies and actions to promote health and well-being in an integral and territorialized way (Cortez, Souza, \& Oliveira, 2018).

Concerning the effect of proximal (intra-individual variables and connections with $\mathrm{O} \& \mathrm{~L}$ ) and distal (macro variables) variables, there is a decreasing hierarchy in the magnitude of the effects listed in the studies included in the meta-analysis. The intra-individual variables varied between -0.11 and 0.65 , while the connections with O\&L and the macro variables varied between -0.12 and 0.52 , and -0.03 and 0.34 , respectively. In this sense, based on Psychology literature's evidence, the effect of intra-individual aspects is predominant on the prediction of employee well-being. Based on this dynamic, we propose two explanatory hypotheses. The first hypothesis considers a prevalent focus on individual aspects in the Psychology literature, 
which explains the predominance of this level (Puente-Palacios \& Laros, 2009). The second hypothesis considers that the impacts of connections with O\&L and the macro variables on work contexts demand interdisciplinary contributions (Alagaraja \& Shuck, 2015).

Thus, the hierarchical impact of these variables can be only totally calculated if we include mixed models, which can integrate the data we analyzed with those generated by meta-analysis performed in other fields of knowledge, such as Administration, Production Engineering, Public Health, among others. Even so, the meta-analysis models proposed in this study make an important preliminary contribution as it investigates the Brazilian Psychology literature to understand how employee well-being can be positively and negatively affected at different levels of analysis.

\section{CONCLUSION}

According to the Psychology literature, work-related well-being may be fostered by actions involving intra-individual variables, connections with O\&L and macro variables. Thus, managers and other stakeholders involved in the decision-making process and strategies of organizations can promote employee well-being by favoring occupational health programs with an emphasis on employee development, stress management and self-regulation; creating positive management conditions to provide material and symbolic support to workers; and acting in favor of organizations whose policies and missions are supported by ideals of social justice and citizenship for all individuals involved. In order to prevent a negative impact on employee wellbeing, some situations should be avoided: unsystematic personnel management practices - especially those that ignore work overload and psychosocial problems in work contexts -, casualization of management conditions and material and symbolic support provided to workers, and development of organizations whose purposes are merely instrumental, autocratic or directed to restrictive political interests.

A research limitation is the impossibility of previously articulating evidence proposed to Administration and to other fields, given the need to previously systematize knowledge in Psychology, which limits the generalization of the evidence found. Another limitation is the impossibility of assessing the relationship between national and international productions, which should be investigated in further studies. Moreover, this study was based on investigations that used exclusively self-reported scales, which 
may be affected by social desirability (McGrath, Mitchell, Kim, \& Hough, 2010). Common variance of the method may also have occurred in the original studies (Chang, Witteloostuij, \& Eden, 2010). Thus, further studies can use other measures and present strategies to minimize problems arising from them. Further studies can also include a careful analysis of the quality level and bias of the evidence reported in the studies sampled, in order to optimize the integrations generated from the present study with other areas and contexts, including international literature.

In conclusion, this study presents the possibilities of convergence between Psychology and Administration concerning employee well-being, which can be explored as a field of investigation and practice. The contribution of this study also lies in the identification of the predictor effects of employee well-being, which offers preliminary evidence for the development of evidence-based and high-impact people management policies and practices through a possible interdisciplinary association between Psychology, Administration and related areas.

\section{PREDITORES DE BEM-ESTAR EM TRABALHADORES IDENTIFICADOS NA LITERATURA DE PSICOLOGIA NO BRASIL}

\section{)} RESUMO

Objetivo: O presente estudo objetivou identificar os efeitos desencadeados por preditores de bem-estar em trabalhadores relacionados na literatura brasileira em Psicologia.

Originalidade/valor: O bem-estar dos trabalhadores está entre os focos fundamentais para otimização das condições laborais e desempenho nas organizações. Há uma larga tradição de investigação sobre o fenômeno, no entanto não há clareza na literatura brasileira sobre os fatores preditores de bem-estar em trabalhadores.

Design/metodologia/abordagem: Primeiramente, cinco estudos foram resgatados por meio de revisão de literatura com o uso do descritor "bem-estar" no portal de Periódicos Eletrônicos em Psicologia (PePSIC) e aplicação de critérios de inclusão e exclusão. Em seguida, as evidências dessas investigações foram compiladas para metanálise, por meio do software Jamovi 0.9.5.12 e o plugin MAJOR Meta-analysis 1.0.0 R. 
Resultados: Os resultados demonstraram que a predição de bem-estar em trabalhadores por meio de variáveis intraindividuais, vínculos com organizações e trabalho (O\&T) e variáveis de nível macro apresenta clareza entre aquelas que impactaram positiva e negativamente. No entanto, são necessários estudos ulteriores, principalmente em interface com a Administração e outras áreas, para otimizar o potencial de generalização dos efeitos encontrados. Em suma, o presente estudo contribui com evidências preliminares para a elaboração de políticas e práticas de gestão de pessoas baseadas em evidências e com alto impacto por meio da proposição de uma possível associação interdisciplinar entre saberes da Psicologia e Administração.

\section{PALAVRAS-CHAVE}

Bem-estar. Condições de trabalho. Trabalho. Revisão de literatura. Metanálise.

\section{REFERENCES}

Adler, M. D., \& Fleurbaey, M. (Eds.) (2016). The Oxford handbook of well-being and public policy. New York: Oxford University Press.

Alagaraja, M., \& Shuck, B. (2015). Exploring organizational alignmentemployee engagement linkages and impact on individual performance: A conceptual model. Human Resource Development Review, 14(1), 17-37. doi:10.1177/1534484314549455

Albuquerque, A. S., \& Tróccoli, B. T. (2004). Desenvolvimento de uma escala de bem-estar subjetivo. Psicologia: Teoria e Pesquisa, 20(2), 153-164. Retrieved from http://www.scielo.br/pdf/\%0D/ptp/v20n2/a08v20n2.pdf

Allen, M. S., \& McCarthy, P. J. (2015). Be happy in your work: The role of positive psychology in working with change and performance. Journal of Change Management, 16(1), 55-74. doi:10.1080/14697017.2015.1128471

Alves, V. D. D., Neiva, E. R., \& Paz, M. D. G. T. (2014). Configurações de poder, suporte organizacional e bem-estar pessoal em uma organização pública. Psicologia em Pesquisa, 8(2), 159-169. doi:10.5327/Z1982-12472 01400020005 
American Psychological Association (2005). Evidence-Based Practice in Psychology. Retrieved from https://www.apa.org/pubs/journals/features/ evidence-based-statement.pdf

Arcidiacono, C., \& Di Martino, S. (2016). A critical analysis of happiness and well-being. Where we stand now, where we need to go. Community Psychology in Global Perspective, 2(1), 6-35. doi:10.1285/i24212113v2i1p6

Bakker, A. B., \& Demerouti, E. (2007). The job demands-resources model: State of the art. Journal of Managerial Psychology, 22, 309-328.

Bendassolli, P. F. (2012). Desempenho no trabalho: Revisão da literatura. Psicologia Argumento, 30(68), 171-186. doi:10.7213/psicol.argum.5895

Bliese, P. D., Edwards, J. R., \& Sonnentag, S. (2017). Stress and well-being at work: A century of empirical trends reflecting theoretical and societal influences. Journal of Applied Psychology, 102(3), 389-402. doi:10.1037/apl 0000109

Boehs, S. D. T. M., Medina, P. F., Bardagi, M. P., Luna, I. N., \& Silva, N. (2017). Revisão da literatura latino-americana sobre aposentadoria e trabalho: Perspectivas psicológicas. Revista Psicologia: Organizações e Trabalho, 17(1), 54-61. doi:10.17652/rpot/2017.1.11598.

Bowling, N. A., Eschleman, K. J., \& Wang, Q. (2010). A meta-analytic examination of the relationship between job satisfaction and subjective wellbeing. Journal of Occupational and Organizational Psychology, 83 (4), 915-934. doi:10.1348/096317909x478557

Breslow, S. J., Sojka, B., Barnea, R., Basurto, X., Carothers, C., Charnley, S., ... \& Hicks, C. C. (2016). Conceptualizing and operationalizing human wellbeing for ecosystem assessment and management. Environmental Science $\mathcal{E}$ Policy, 66, 250-259. doi:10.1016/j.envsci.2016.06.023

Brockwell, S. E., \& Gordon, I. R. (2001). A comparison of statistical methods for meta-analysis. Statistics in Medicine, 20(6), 825-840. doi:10.1002/sim.650

Burnham, K. P., \& Anderson, D. R. (2004). Multimodel inference: Understanding AIC and BIC in model selection. Sociological Methods \& Research, 33(2), 261-304. doi:10.1177/0049124104268644

Cardoso, M. D. C. B., \& Araújo, T. M. D. (2016). Workers' Health Reference Centers performance in mental health: A survey in Brazil. Revista Brasileira de Saúde Ocupacional, 41 (7), 1-14. doi:10.1590/2317-6369000118115

Carneiro, L. L., \& Fernandes, S. R. P. (2015). Bem-estar pessoal nas organizações e lócus de controle no trabalho. Revista Psicologia: Organizações e Trabalho, 15(3), 257-270. doi:10.17652/rpot/2015.3.599 
Chang, S. J., Witteloostuij, A. V., \& Eden, L. (2010). Common method variance in international business research. Journal of International Business Studies, 41, 178-184. Rcuperado de https://link.springer.com/article/10.1057/ jibs.2009.88

Cortez, P. A., Souza, M. V. R., Salvador, A. P., \& Oliveira, L. F. A. (2019). Sexismo, misoginia e LGBTQfobia: Desafios para promover o trabalho inclusivo no Brasil. Physis: Revista de Saúde Coletiva, 29(4), e290414. doi:10. 1590/S0103-73312019290414

Cortez, P. A., Souza, M. V. R. D., Amaral, L. O., \& Silva, L. C. A. D. (2017). A saúde docente no trabalho: Apontamentos a partir da literatura recente. Cadernos Saúde Coletiva, 25(1), 113-122. doi:0.1590/1414-462×2017000 10001

Cortez, P. A., Souza, M. V. R. D., \& Oliveira, L. F. A. (2018). Princípios de uma política alternativa aos manicômios judiciais. Saúde e Sociedade, 27(4), 1206-1217. doi: 10.1590/s0104-12902018180409

Cortez, P. A., Veiga, H. M. D. S., Gomide, A. P. D. Á., \& Souza, M. V. R. D. (2019). Suicídio no trabalho: Um estudo de revisão da literatura brasileira em psicologia. Revista Psicologia: Organizações e Trabalho, 19(1), 523-531. doi: $10.17652 / \mathrm{rpot} / 2019.1 .14480$

Cortez, P. A., Zerbini, T., \& Veiga, H. M. D. S. (2019). Práticas humanizadas de gestão de pessoas e organização do trabalho: Para além do positivismo e do dataísmo. Trabalho, Educação e Saúde, 17(3), 1-23. doi:10.1590/19817746-sol00215

Cortez, P. A., Zerbini, T., \& Veiga, H. M. D. S. (2019). Work context and burnout: Confirmation of moderators from meta-analysis evidence. Revista Psicologia: Organizações e Trabalho, 19(4), 755-761. doi:10.17652/rpot/2019. 4.17499

Danna, K., \& Griffin, R.W. (1999). Health and well-being in the workplace: A review and synthesis of the literature. Journal of Management, 25(3), 357-384. doi:10.1177/014920639902500305

Deci, E. L., \& Ryan, R. M. (2008). Hedonia, eudaimonia, and well-being: An introduction. Journal of Happiness Studies: An Interdisciplinary Forum on Subjective Well-Being, 9(1), 1-11. doi:101007/s10902-006-9018-1

Demerouti, E., Bakker, A. B., Nachreiner, F., \& Schaufeli, W. B. (2001). The job demands resources model of burnout. Journal of Applied Psychology, 86, 499-512.

Dessen, M. C., \& Paz, M. D. G. T. (2010). Validação do instrumento de indicadores de bem-estar pessoal nas organizações. Psicologia em Estudo, 15(2), 409-418. Retrieved from http://www.scielo.br/pdf/pe/v15n2/a20v15n2 
Diener, E., Oishi, S., \& Tay, L. (2018). Introduction by the editors. In E. Diener, S. Oishi, \& L. Tay (Eds.). Handbook of well-being. Salt Lake City, UT: DEF.

Di Fabio, A., \& Kenny, M. E. (2016). From decent work to decent lives: Positive self and relational management (PS\&RM) in the twenty-first century. Frontiers in Psychology, 7(1), 361-373. doi:10.3389/fpsyg.2016.00361

Donaldson, S. I., Dollwet, M., \& Rao, M. A. (2015). Happiness, excellence, and optimal human functioning revisited: Examining the peer-reviewed literature linked to positive psychology. The Journal of Positive Psychology, 10(3), 185-195. doi:10.1080/17439760.2014.943801

Douglas, O., Lennon, M., \& Scott, M. (2017). Green space benefits for health and well-being: A life-course approach for urban planning, design and management. Cities, 66, 53-62. doi:10.1016/j.cities.2017.03.011

Ferraz, R., \& Lopes, E. (2015). Satisfação no trabalho: Comparação de duas escalas de medida por meio de equações estruturais. Revista de Gestão dos Países de Língua Portuguesa, 14(1), 37-47. Retrieved from http://www.scielo. mec.pt/scielo.php? script=sci_arttext\&pid=S1645-44642015000100005

Ferreira, M. C. P., \& Torres, A. R. R. (2001). Bancários portadores de distúrbios osteomusculares relacionados ao trabalho e identidade profissional. Estudos - Vida e Saúde, 28(4), 746-781. Retrieved from http://www.scielo. br/scielo.php? script $=$ sci_nlinks\&ref $=000125 \&$ pid $=$ S1414 -98932005000 40001000011\&lng $=\mathrm{pt}$

Fredrickson, B. (2004). The broaden-and-build theory of positive emotions. The Royal Society, 359, 1367-1377. doi:10.1098/rstb.2004.1512

Fredrickson, B. L. (1998). What good are positive emotions? Review of General Psychology, 2, 300-319. doi:10.1037/1089-2680.2.3.300

Garcez, L., Antunes, C. B. L., \& Zarife, P. S. (2018). Bem-estar no trabalho: Revisão sistemática da literatura brasileira. Aletheia, 51 (1-2), 143-155. Retrieved from http://www.periodicos.ulbra.br/index.php/aletheia/article/ view/4918/3265

Görgens-Ekermans, G., \& Styn, R. (2016). Optimism, self-efficacy and meaningfulness: A structural model of subjective well-being at work. Management Dynamics, 25(4), 34-51. Retrieved from https://www.questia.com/library/ journal/1P4-2064336317/optimism-self-efficacy-and-meaningfulness-astructural

Guest, D. E. (2017). Human resource management and employee wellbeing: Towards a new analytic framework. Human Resource Management Journal, 27(1), 22-38. doi:10.1111/1748-8583.12139 
Hamilton, K. (2018). MAJOR Metanalysis 1.0.0. Retrieved from http:// kylehamilton.com/publication/major/

Harter, J. K., Schmidt, F. L., \& Keyes, C. L. M. (2003). Well-being in the workplace and its relationship to business outcomes. A review of the Gallup studies. In C. L. M. Keyes \& J. Haidt (Eds.), Flourishing: The positive person and the good life. Washington, DC: American Psychological Association.

Hirschle, A. L. T., Gondim, S. M. G., Alberton, G. D., \& Ferreira, A. D. S. M. (2019). Estresse e bem-estar no trabalho: O papel moderador da regulação emocional. Revista Psicologia: Organizações e Trabalho, 19(1), 532-540. doi:10.17652/rpot/2019.1.14774

Hobfoll, S. E. (1989). Conservation of resources: A new attempt at conceptualizing stress. American Psychologist, 44, 513-524. doi:10.1037/0003066X.44.3.513

Houben, M., Noortgate, W. V. D., \& Kuppens, P. (2015). The relation between short-term emotion dynamics and psychological well-being: A metaanalysis. Psychological Bulletin, 141 (4), 901-930. doi:10.1037/a0038822

Jamovi. (2018). Jamovi 0.9.5.12. Retrieved from https://www.jamovi.org

Katic, I., \& Ingram, P. (2018). Income inequality and subjective well-being: Toward an understanding of the relationship and its mechanisms. Business \& Society, 57(6), 1010-1044. doi:10.1177/0007650317701226

Keyes, C. L. M., Shmotkin, D., \& Ryff, C. D. (2002). Optimizing well-being: The empirical encounter of two traditions. Journal of Personality and Social Psychology, 82, 1007-1022. doi:10.1037//0022-3514.82.6.1007

Lyubomirsky, S., King, L., \& Diener, E. (2005). The benefits of frequent positive affect: Does happiness lead to success? Psychological Bulletin, 131, 803-855. doi:10.1037/0033-2909.131.6.803

McGrath, R. E., Mitchell, M., Kim, B. H., \& Hough, L. (2010). Evidence for response bias as a source of error variance in applied assessment. Psychological Bulletin, 136(3), 450-70. doi:10.1037/a0019216

Moen, P., Kelly, E. L., Fan, W., Lee, S. R., Almeida, D., Kossek, E. E., \& Buxton, O. M. (2016). Does a flexibility/support organizational initiative improve high-tech employees' well-being? Evidence from the work, family, and health network. American Sociological Review, 81 (1), 134-164. doi:10. $1177 / 0003122415622391$

Moher, D., Liberati, A., Tetzlaff, J., Altman, D. G., \& Prisma Group (2009). Preferred reporting items for systematic reviews and meta-analyses: The PRISMA statement. BMJ, 339(b2535), 1-8. doi:10.1136/bmj.b2535 
Müller, A., Heiden, B., Herbig, B., Poppe, F., \& Angerer, P. (2016). Improving well-being at work: A randomized controlled intervention based on selection, optimization, and compensation. Journal of Occupational Health Psychology, 21(2), 169-181. doi:10.1037/a0039676

Orwin, R. G. (1983). A Fail-Safe N for effect size in meta-analysis. Journal of Educational Statistics, 8(2), 157-159. doi:10.3102/10769986008002157

O’Sullivan, D. (2010). Metanálise. In G. M. Breakwell, S. Hammond, C. FifeSchaw, J. A. Smith, \& V. G. Haase (Orgs.), Métodos de pesquisa em psicologia. Porto Alegre: Artmed.

Pantaleão, P. F., \& Veiga, H. M. S. (2019). Bem-estar no trabalho: Revisão sistemática da literatura nacional na última década. Holos, 5(1), 1-24. doi:10.15628/holos.2019.7570

Paschoal, T., \& Tamayo, A. (2008). Construção e validação da escala de bem-estar no trabalho. Avaliação Psicológica, 7(1), 11-22. Retrieved from http:// pepsic.bvsalud.org/scielo.php? script $=$ sci_arttext $\&$ pid $=$ S1677-0471200 8000100004

Paz, M. G. T. (2004). Poder e saúde organizacional. In A. Tamayo (Org.), Cultura e saúde nas organizações (pp. 127-154). Porto Alegre: Artmed.

Peterson, R. A., \& Brown, S. P. (2005). On the use of beta coefficients in meta-analysis. Journal of Applied Psychology, 90(1), 175-181. doi:10.1037/ 0021-9010.90.1.175

Prilleltensky, I. (2008). The role of power in wellness, oppression, and liberation: The promise of psychopolitical validity. Journal of Community Psychology, 36(2), 116-136. doi:10.1002/jcop.20225

Pruyne, E. (2011). Corporate investment in employee wellbeing: The emerging strategic imperative. Hertfordshire: Ashridge Business School and Nuffield Health.

Puente-Palacios, K. E., \& Laros, J. A. (2009). Análise multinível: Contribuições para estudos sobre efeito do contexto social no comportamento individual. Estudos de Psicologia, 26(3), 349-361. doi:10.1590/S0103-166X2009 000300008

Robertson, I., \& Cooper, C. (2011). Well-Being, productivity and happiness at work. Basingstoke: Palgrave Macmillan.

Ryan, R. M., \& Deci, E. L. (2001). On happiness and human potentials: A review of research on hedonic and eudaimonic well-being. Annual Review of Psychology, 52, 141-166. doi:10.1146/annurev.psych.52.1.141

Ryff, C. D., \& Keyes, C. L. (1995). The structure of psychological well-being revisited. Journal of Personality and Social Psychology, 69 (4), 719-727. doi:10. 1037/0022-3514.69.4.719 
Santos, G. B., \& Ceballos, A. G. D. C. D. (2013). Bem-estar no trabalho: Estudo de revisão. Psicologia em Estudo, 18(2), 247-255. doi:10.1590/S1 413-73722013000200006

Santos, J. X., Torres, A. R. R., \& Zanini, D. S. (2011). Bem-estar, lócus de controle e crença no mundo justo de trabalhadores da saúde. Aletheia, 35-36. Retrieved from http://www.periodicos.ulbra.br/index.php/ aletheia/article/view/3429/2565

Seligman, M. E. P., \& Csikszentmihalyi, M. (2000). Positive Psychology: An introduction. American Psychologist, 55(1), 5-14. doi:10.1037/0003066X.55.1.5

Silver, N. C., \& Dunlap, W. P. (1987). Averaging correlation coefficients: Should Fisher's z transformation be used? Journal of Applied Psychology, 72(1), 146-148. doi:10.1037/0021-9010

Siqueira, M. M. M. (2008). Satisfação no trabalho. In M. M. M. Siqueira (Org.), Medidas do comportamento organizacional: Ferramentas de diagnóstico e de gestão (pp. 257-266). Porto Alegre: Artmed.

Siqueira, M. M. M., \& Padovam, V. A. R. (2008). Bases teóricas de bem-estar subjetivo, bem-estar psicológico e bem-estar no trabalho. Psicologia: Teoria e Pesquisa, 24(2), 201-209. doi:10.1590/S0102-37722008000200010

Snyder, C. R., \& Lopez, S. J. (Eds.), (2002). Handbook of positive psychology. New York: Oxford University Press.

Sonnentag, S. (2015). Dynamics of well-being. Annual Review of Organizational Psychology and Organizational Behavior, 2(1), 261-293. doi:10.1146/ annurev-orgpsych-032414-111347

Souza, G. C. D., Aguiar, C. V. N., \& Carneiro, L. L. (2018). A influência dos vínculos com a organização sobre o bem-estar subjetivo do trabalhador. Revista Psicologia: Organizações e Trabalho, 18(4), 460-467. doi:10.17652/ rpot/2018.4.13727

Sterne, J. A., Sutton, A. J., Ioannidis, J. P., Terrin, N., Jones, D. R., Lau, J., ... \& Tetzlaff, J. (2011). Recommendations for examining and interpreting funnel plot asymmetry in meta-analyses of randomised controlled trials. BMJ, 343(1), d4002-d4002. doi:10.1136/bmj.d4002

Stroup, D. F., Berlin, J. A., Morton, S. C., Olkin, I., Williamson, G. D., Rennie, D., ... \& Thacker, S. B. (2000). Meta-analysis of observational studies in epidemiology: A proposal for reporting. Jama, 283 (15), 20082012. doi:10.1001/jama.283.15.2008 
Urrútia, G., \& Bonfill, X. (2010). Declaración PRISMA: Una propuesta para mejorar la publicación de revisiones sistemáticas y metaanálisis. Medicina Clínica, 135(11), 507-511.

Van Den Heuvel, M., Demerouti, E., \& Peeters, M. C. (2015). The job crafting intervention: Effects on job resources, self-efficacy, and affective wellbeing. Journal of Occupational and Organizational Psychology, 88 (3), 511-532. doi: 10.1111/joop.12128

Van Wingerden, J., Bakker, A. B., \& Derks, D. (2017). Fostering employee well-being via a job crafting intervention. Journal of Vocational Behavior, 100 (1), 164-174. doi:10.1016/j.jvb.2017.03.008

\section{AUTHOR NOTES}

Heila M. S. Veiga, Ph.D. from the Institute of Psychology, University of Brasília (UnB); Pedro A. Cortez, Ph.D. from the Postgraduate Program in Psychology, São Francisco University (USF).

Heila M. S. Veiga is now associate professor at the Institute of Psychology of Federal University of Uberlândia (UFU); Pedro A. Cortez is now professor at the Postgraduate Program in Psychology of Tuiuti University of Paraná (UTP).

Correspondence concerning this article should be addressed to Heila M. S. Veiga, campus Universitário Umuarama, bloco 2C, sala 22, Umuarama, Uberlândia, Minas Gerais, Brazil, CEP 38405-318. E-mail: heila.veiga@gmail.com

\section{EDITORIAL BOARD}

Editor-in-chief

Gilberto Perez

Associated Editor Gardênia da Silva Abbad

Technical Support Vitória Batista Santos Silva

\section{EDITORIAL PRODUCTION}

Publishing Coordination

Jéssica Dametta

Layout Designer

Editorial Intern

Paula Di Sessa Vavlis

Emap

Graphic Designer

Libro

Language Editor

Daniel de Almeida Leão 